Canadian Journal of Higher Education

Revue canadienne d'enseignement supérieur

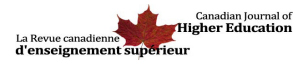

\title{
Left Out in the Academic Field: Doctoral Graduates Deal with a Decade of Disappearing Jobs
}

\section{Sandra Acker et Eve Haque}

Volume 47, numéro 3, 2017

URI : https://id.erudit.org/iderudit/1043240ar

DOI : https://doi.org/10.7202/1043240ar

Aller au sommaire du numéro

\section{Éditeur(s)}

Canadian Society for the Study of Higher Education

ISSN

2293-6602 (numérique)

Découvrir la revue

Citer cet article

Acker, S. \& Haque, E. (2017). Left Out in the Academic Field: Doctoral Graduates Deal with a Decade of Disappearing Jobs. Canadian Journal of Higher Education / Revue canadienne d'enseignement supérieur, 47(3), 101-119.

https://doi.org/10.7202/1043240ar
Résumé de l'article

En 2001-2002, les auteurs de cet article ont interviewé 31 doctorants d'origines et de cultures diverses au sujet de leurs expériences d'études en sociologie de l'éducation dans une université canadienne. Environ 10 ans plus tard, dans une deuxième étude qualitative, ces mêmes auteurs ont eu la possibilité de diriger des entrevues semi-structurées avec 13 des étudiants de la première cohorte d'entrevues (aujourd'hui diplômés) afin de découvrir ce qui s'était passé sur le plan professionnel entre les deux entrevues. Deux d'entre eux étaient devenus des titulaires universitaires permanents, trois autres étaient en voie d'obtenir une permanence après des années dans des postes temporaires, tandis que la plupart des autres travaillaient dans le secteur indéterminé du marché du travail universitaire. Les concepts de Bourdieu ont été particulièrement utiles pour la présente analyse. En effet, pour les participants de l'étude, les auteurs explorent les tensions entre « habitus » et « champ ".
Copyright (c) Sandra Acker, Eve Haque, 2017

Attribution-NonCommercial-No Derivative Works 2.5 Canada
Ce document est protégé par la loi sur le droit d'auteur. L'utilisation des services d'Érudit (y compris la reproduction) est assujettie à sa politique d'utilisation que vous pouvez consulter en ligne.

https://apropos.erudit.org/fr/usagers/politique-dutilisation/ 
Canadian Journal of Higher Education Revue canadienne d'enseignement supérieur

Volume 47, No. 3, 2017, pages $101-119$

\title{
Left Out in the Academic Field: Doctoral Graduates Deal with a Decade of Disappearing Jobs
}

Sandra Acker

University of Toronto

Eve Haque

York University

\begin{abstract}
In 2001-2002, the authors of this article interviewed 31 ethno-culturally diverse doctoral students about their experiences in a sociology of education program at a Canadian university. Approximately 10 years later, in a second qualitative study, we had the chance to conduct semi-structured interviews with 13 of the former students to find out what had happened to them in the intervening years. Two of the 13 had become tenured academics, three were on the tenure track after years in temporary positions, and most of the others worked in the contingent sector of the academic labour market. Bourdieu's concepts of "habitus" and "field" are particularly useful for our analysis, and we explore the tensions between these concepts for our participants.
\end{abstract}

\section{Résumé}

En 2001-2002, les auteurs de cet article ont interviewé 31 doctorants d'origines et de cultures diverses au sujet de leurs expériences d'études en sociologie de l'éducation dans une université canadienne. Environ 10 ans plus tard, dans une deuxième étude qualitative, ces mêmes auteurs ont eu la possibilité de diriger des entrevues semi-structurées avec 13 des étudiants de la première cohorte d'entrevues (aujourd'hui diplômés) afin de découvrir ce qui s'était passé sur le plan professionnel entre les deux entrevues. Deux d'entre eux étaient devenus des titulaires universitaires permanents, trois autres étaient en voie d'obtenir une permanence après des années dans des postes temporaires, tandis que la plupart des autres travaillaient dans le secteur indéterminé du marché du travail universitaire. Les concepts de Bourdieu ont été particulièrement utiles pour la présente analyse. En effet, pour les participants de l'étude, les auteurs explorent les tensions entre « habitus 》 et 《 champ 》. 


\section{Introduction}

Labour market conditions for advanced degree holders have become a topic of concern in Canada and elsewhere, as full-time, permanent academic positions become increasingly unavailable (Fullick, 2013; Gillis, 2013; Neumann \& Tan, 2011). Yet we rarely find an analysis of doctoral graduates' reflections on their struggles and successes over time. In 2001-2002, the authors of this article conducted a qualitative, interview-based study of 31 doctoral students-diverse in age, gender, family situation, and ethno-cultural backgrounds-enrolled in a sociology of education program at a Canadian university. Results are reported elsewhere (Acker \& Haque, 2010, 2015). Here we describe a subsequent study of 13 of the original participants about a decade later. We consider what kind of transition to the workplace these former doctoral students have faced and how they felt about it.

\section{Background}

Studies from various countries report between a fifth and a third of doctoral recipients obtain full-time tenured or tenure-track academic positions a few years after graduation (Jonker, 2016, p. 14; Mellors-Bourne, Metcalfe, \& Pollard, 2013, p. 12; Neumann \& Tan, 2011, p. 604). However, the studies also predict a long-term global decline in the proportions of doctoral graduates who will be employed in academia, an assessment at odds with the wish of many doctoral students to become academics (Maldonado, Wiggers, \& Arnold, 2013; Morrison, Rudd, \& Nerad, 2011). While students in the humanities and social sciences are particularly affected, those in the sciences are not immune from the lure of academe (Gemme \& Gingras, 2012).

As of 2010-2011, approximately 45,000 academics were employed full time in Canadian universities (Statistics Canada, 2012, Table 477-0017). About 6,600 new doctorates graduate each year (Ferguson \& Wang, 2014, Table A.1), and others enter the country as immigrants or returning Canadians with doctorates from elsewhere (Edge \& Munro, 2015, p. 18). Yet it has been estimated that only 1,500 to 2,000 tenure-track positions are advertised annually (Chiose, 2015). An analysis of 2011 National Household Survey data found that despite $39.4 \%$ of doctorate-holders being employed in the postsecondary education sector in some capacity, only $18.6 \%$ were working as full-time university faculty (Edge \& Munro, 2015, pp. 16-17). However, Jonker (2016), using Internet resources to track 2,310 graduates who earned a 2009 Ontario university doctoral degree, reported a higher percentage of $29 \%$ who were full-time tenured or tenure-track university professors as of 2015 (p. 14). Another 21\% held other jobs within academia, and 35\% were employed outside the academic field; $15 \%$ could not be located (p. 14). The disparate results of these two studies are likely due to different methodologies. While Edge and Munro looked at proportions of the doctorate-holding population in Canada aged 25 to 64 who were employed in Canadian universities (including those with doctorates from outside the country), Jonker followed a specific cohort of Ontario doctoral graduates over six years, including those employed in Canada and abroad (Jonker, 2016, p. 9).

For those graduates who cannot find a permanent academic position, contingent teaching is one alternative. Contingent positions range from "sessional" or "stipend" appointments to teach a specific course in a given term to contracts of longer duration that are nevertheless time-limited and do not lead to tenure. These positions carry no guarantee of permanence or job security, and conditions and benefits are inferior to those of 
regular faculty (Bauder, 2006; Field \& Jones, 2016). Numbers of contingent academic workers in Canadian postsecondary education appear to be rising rapidly (Jones, 2013; OCUFA, 2014), although lack of readily available data hampers efforts to be specific about trends (Brownlee, 2015; Field \& Jones, 2016).

Exacerbating the problem of doctoral employability in Canada are large increases in numbers of doctoral students, and thus graduate job-seekers, in the last few decades (Tamburri, 2013). In the province of Ontario, universities nearly doubled their doctoral enrolment between 1999 and 2009 (Maldonado et al., 2013, p. 3).The impetus appears to have been the anticipation of faculty shortages caused by impending retirements-unwarranted, as it turned out-and government efforts to produce highly qualified people who can compete in a global economy (Maldonado et al., 2013; Tamburri, 2013). At the same time, budget constraints and the dictates of corporatization have encouraged university administrators to hire contingent teachers instead of more expensive full-time faculty. The imbalance between numbers of academic job-seekers and available positions has stimulated discussion of graduate school reform (e.g., Modern Language Association, 2014; White Paper , 2013) and better preparation for careers outside academia. This discussion includes provision in doctoral programs of what are variously called generic, soft, transferable, or professional development skills or graduate attributes (Kehm, 2009; Manathunga, Pitt \& Critchley, 2009; Platow, 2012). While in the UK, Australia, and some other countries, integrating generic skills into doctoral programs has become the norm (Golovushkina \& Milligan, 2012; Manathunga et al., 2009; OECD, 2012), in Canada such efforts are largely voluntary (OECD, 2012; Sekuler, Crow, \& Annan, 2013). Another roadblock appears to be Canadian businesses' reluctance to hire PhDs (Edge \& Munro, 2015, pp. 32-33).

With a few exceptions (e.g., McAlpine, Amundsen, \& Turner, 2013), research rarely gives a picture of the experiential side of the (attempted) transition from doctoral studies to a port of academic safety. Nor do many studies collect information on doctoral graduates' careers beyond a few years after graduation. Our data enable us to make a contribution to the understanding of doctoral career outcomes over time. Specifically, we consider the following questions in this article:

1. What career pathways are found among the participants?

2. How do the participants reflect upon and interpret the structural factors shaping their career situations?

3. How do the participants reflect upon and interpret the personal factors shaping their career situations?

\section{Theoretical Framework and Review of Relevant Literature}

As we attempted to understand what happened to our participants over the intervening years, we were drawn to certain ideas of the French sociologist Pierre Bourdieu, particularly his interrelated concepts of field and habitus and to a lesser extent capital, illusio, and hysteresis. Bourdieu (1998) considered that habitus, field, and capital were his key concepts, illuminating "the two-way relationship between objective structures (those of social fields) and incorporated structures (those of the habitus)" (p. vii).

Bourdieu wrote about the scientific field $(1975 ; 2004)$ and the academic field (1988) that he saw as (overlapping) sites containing "forces" and "struggles" (2004, p. 33). The structure of a field is defined "by the state of power relations between protagonists in the struggle" (p. 59). Protagonists, or agents, display dispositions and accumulate capital of 
various kinds through previous experiences and take up positions that involve making choices based on their perceptions of "the space of possibles" (pp. 59-60). There is "room for manoeuvre" (p. 35) and thus the field can be changed by the actions of agents while also changing them in the process (p. 33). Fields and subfields may be conceptualized at various levels; for example, in the academic field there are laboratories, institutions, disciplines, and so forth (p. 32). Bourdieu helps us comprehend field dynamics by using the analogy of a game with players, some of whom are more knowledgeable than others about rules and strategies (Bourdieu \& Wacquant, 1992, pp. 98-99).

Field should be understood in conjunction with habitus. An individual's primary habitus is the sum total of dispositions, embodied and usually unconscious, laid down through early socialization and shaping what is regarded as thinkable or unthinkable (the "space of possibles"). Bourdieu (1998) also describes habitus as a "kind of practical sense for what is to be done in a given situation" or a "feel for the game" (p. 25). As life goes on, habitus alters through experience, and is not a deterministic predictor of outcomes: "durable but not eternal" (Bourdieu \& Wacquant, 1992, p. 133). Some forms of habitus mesh well with a field, while others are at odds with it or require new learning.

Bourdieu (1986) is also credited with extending the familiar use of capital beyond an economic notion-power resting upon money, property, and material goods-to encompass other forms, notably social capital (networks, connections) and cultural capital (mannerisms, practices, credentials). Social and cultural capital are important resources within educational fields, where the consequences of familial cultural capital can be readily confused with "talent" and "merit." Bourdieu (1984) states that the "educational system ... governs the conversion of inherited cultural capital into educational capital" (p. 73).

Bourdieu's work has been used in studies of access to higher education (Baker, 2014; Reay, David, \& Ball, 2010), postsecondary educational and occupational patterns (Andres \& Adamuti-Trache, 2008), university experiences of differently advantaged students (Bathmaker, Ingram, \& Waller, 2013; Lee \& Kramer, 2013; Lehmann, 2013; Mullen, 2010); graduate and professional education (Gardner \& Holley, 2011; Gopaul, 2011, 2015; Manderson \& Turner, 2006; Mullen, Goyette, \& Soares, 2003; Raineri, 2013), and more generally to analyze higher education and the research enterprise (Albert \& Kleinman, 2011; Lucas, 2006; Mendoza, Kuntz, \& Berger, 2012; Naidoo, 2004). Gopaul's (2011, 2015) research on engineering and philosophy doctoral students, as well as our own earlier work (Acker, 2001; Acker \& Haque, 2010, 2015), illustrates how groups and individuals compete for advantage within the doctoral department field, one where certain attainments (scholarships, publications, conferences, faculty attention) carry value as "capital" but are not equally possessed or achieved by all students.

To pull these strands of theory and research together and apply them to our study, we first consider that during the years of doctoral study, students acquire an "academic habitus" (Deem \& Lucas, 2007) as a sort of gloss on their primary habitus that they will take with them into the next stages of their careers. While it is logical that the academic habitus will splinter into disciplinary and even departmental forms, there are likely to be common elements, such as those identified by Zipin and Brennan (2003) as an inclination to be reflexive, ethical, and collegial. To this list we would add a belief that working hard and achieving excellence will bring appropriate rewards, such as securing a tenuretrack faculty position leading to an academic career. 
Following Bourdieu, we expect that those who succeed are often the individuals whose habitus leads them to have a "feel for the game," or in an oft-quoted and colourful metaphor, to be "fish in water" in a particular field (Bourdieu \& Wacquant 1992, p. 127). This perspective might mean that the original habitus overlaid by the academic one will be a deciding factor, or that the pieces of academic capital (publications, teaching experience, mentoring) picked up during doctoral study will be the key to acquiring a preferred position. Put in more general terms, our main interest is in what happens when the academic habitus tries to find expression within the increasingly constricted academic labour field. One might suggest that the academic habitus contains what Bourdieu called an illusio, the belief players hold in the seriousness of the "game" and the desirability of its rewards (Bourdieu, 1988, p. xii, p. 56; 2000, p. 11), despite any reductions in the probability of achieving them.

In this case, we would expect illusio to produce what Bourdieu termed hysteresis or hysteresis of habitus for individuals who value a tenure-track position above other possibilities but find it difficult or impossible to attain. Hysteresis occurs when rapid social change in a field means that a habitus formerly adapted to it no longer works effectively (Bourdieu, 1984, p. 138). In Pascalian Meditations (2000), Bourdieu tells us that the habitus has "degrees of integration" to its situation and that "there is an inertia (or hysteresis)" that perpetuates dispositions even when no longer adapted to a field experiencing crisis or profound change (p. 160). His (1988) study of the academic field in France around 1968 depicts a situation in which lecturers whose academic habitus led them to anticipate a secure career pathway to professorship found that changing realities of the field thwarted their aspirations. Although Bourdieu was writing about a field with stronger reproductive dynamics than we see in Canada, it is, nevertheless, worth considering whether our contemporary academic labour market features new rules and realities that might create a "hysteresis of habitus," especially for would-be entrants who are unable to find a permanent academic position.

\section{Method}

As noted above, in 2001-2002, we collaborated on a qualitative interview study of 31 full-time doctoral students in one university department, a sociology of education program in a large, urban, research-intensive university in Ontario, Canada (Acker \& Haque, 2010, 2015). The department considered itself oriented to sociology rather than education, with a particular focus on dimensions of equity such as race, gender, or disability. The 31 students comprised about a quarter of the department's registered doctoral students and were chosen to represent different program points, from those in their early years pursuing coursework to those who were about to graduate, as well as several "lapsed" students who had been registered for a number of years without finishing.

In 2010-2011, Eve Haque, who had conducted the first set of interviews while herself a fellow doctoral student, contacted and interviewed 13 of the 31 about what had happened in their lives since the original study. The interviews lasted around 90 minutes; they were semi-structured, conducted face-to-face, and later transcribed. The study was what Tesch (1990) calls interpretational qualitative analysis, "whose purpose is to discover regularities and research that is meaning-oriented" (p. 98). Analysis proceeded through repeated readings and manual coding by both authors, noting and discussing emergent themes of interest, followed by selective coding of the subtopics reported here. 
Participants were located through personal contacts, web searches, and departmental records. Due to a very restricted budget, we were unable to travel for data collection. We also calculated that we could afford to have around a dozen interviews transcribed and limited the number of interviews accordingly. As a consequence, the selection principle was to some extent one of convenience, as we needed participants who were located within the same broad geographical area as the interviewer or were accessible during a visit or conference. Despite this limitation, the 11 women and two men who were interviewed included persons from a range of ethno-cultural backgrounds (East Asian, Caribbean, Latina/o, Middle Eastern, South Asian, White European) and all of the original program stages. In addition, we were able to trace most of the original 31 students/graduates (as of 2014) through web sites, personal contacts, and departmental information and satisfy ourselves that the individuals chosen for new interviews were broadly similar to the original group as a whole. ${ }^{1}$

As in the original study, participants were concerned about anonymity, even years after graduation, and thus we repeated our earlier practice whereby Eve, now a faculty member, would do the interviews, and Sandra would receive transcripts after they had been anonymized. Eve's guiding questions were designed to allow individuals to tell their stories of ups and downs during graduate school and afterward, rather than to collect systematic data across cases. We were particularly anxious not to give the impression that we were judging our participants; thus we did not ask for CVs or lists of publications or funding records that might have been interpreted in that way.

\section{Findings}

We begin this section with an overview of participants' career outcomes. In keeping with the theoretical framework presented above, subsequent analysis is divided into discussions of field, here interpreted as factors external to the participant, such as the parameters of the doctoral program or the state of the labour market, and habitus, features of the participants' lives such as their family situation or thoughts about their choices and decisions. We also consider how the two categories connect-habitus finding expression within the field.

\section{Pathways}

The interviewees in the current study comprise two who are tenured, three on the tenure track, six currently or recently involved in contingent teaching, and two in stable non-university careers. ${ }^{2}$ All participants had completed their doctorates except for three of the contingent faculty (Candy, Carla, Craig). We have alphabetized the pseudonyms to aid in recalling the categorization:

Tenured

Tenure-track

Contingent

$\mathrm{PhD}$ incomplete

$\mathrm{PhD}$ complete
Alice, Annie

Bella, Ben, Bonnie

Candy, Carla, Craig

Cecile, Charlotte, Corinne

Stable non-university careers Denise, Dinah

Alice was the only participant to find her way into a tenure-track academic position in fewer than two years post-graduation, after several sessional teaching experiences, and 
was the first of the 13 to be tenured. Annie spent four years in postdoctoral and temporary academic appointments before moving to tenure-track and, eventually, tenured employment. Ben, Bonnie, and Bella only recently achieved tenure-track status, all after years in sessional and contract positions. All six participants in the contingent group were working or recently working in universities, one in a part-time administrative role, one on a multi-year contract, and the others in sessional teaching. In the "stable non-university career" category, Denise was located in the elementary and secondary school system, while Dinah owned her own business, unrelated to her doctoral studies. Both Denise and Dinah had hoped for an academic or research career, although they each expressed some reservations about the culture of academe. ${ }^{3}$

Looking briefly at a few characteristics of those who reached the tenure track gives us some idea of what might be required and provides some surprises. Speedy completion of a doctorate did not predict securing a tenure-track position for the current participants or in the larger group. Of the 31 original participants, only one of the thirteen who had obtained tenured or tenure-track academic positions completed their doctorate in less than six years. Despite the widespread belief that time to completion should be shortened, we speculate that there may be a minimum number of years necessary to accumulate the publications and teaching experience expected of a new academic. Holding a postdoctoral research appointment was also unrelated to achieving a tenure-track academic position. Being geographically mobile may have conferred some advantage for our interviewees (McAlpine, 2012; Wood \& Townsend, 2013): four of the five tenured and tenure-track faculty, compared with two of the eight others, spent time working out of country or out of province. While all of those in tenured or tenure-track positions had done contingent teaching, contingent work per se did not necessarily open a door to a permanent position.

In the next sections we use the interviews to delve into the experiential side of our data, looking at how participants themselves understood their journeys. To factors such as teaching experience or time to degree, we add qualities of the field (e.g., job opportunities) and those of habitus (e.g., orientations and decisions).

\section{The Field: The Doctoral Program and the Academic Labour Market}

While many participants recounted good things about their doctoral studies-"the PhD was the most happy time" (Annie); "I loved the esoteric journey that I took" (Candy)-critical statements abounded. Variations on "nobody told me ..." were common. Some participants believed there were important understandings that faculty inconsistently shared with students, for example, the best conferences to attend in terms of later job possibilities (Ben). Carla argued that successfully moving through the doctoral problem required access to what she called "hidden information." She continued:

You need an expert or somebody who has already navigated through it, either successfully or not, to let you know where the things are, because they are not made available to you so you don't know.

Various comments pertained to job preparation:

Annie: It was great to have that kind of academic pursuit . . but I think you need practical skills to, say, work in a research firm, or something like that. 
Dinah: There're a million things I think they could have done. They could have given us some preparation of what to expect with the job market. We really were set adrift.

Participants also talked about supervision and mentoring. Even as a master's student, Alice was collaborating with her professor on research and publications, a relationship that continued throughout her doctorate. Perhaps unexpectedly, given the strength of the mentoring connection, she added that she wrote her $\mathrm{PhD}$ very independently: "I didn't have ongoing meetings." Working independently could have mixed results. As Dinah noted, "because of my perceived independence and ability to accomplish a task, I was kind of left on my own to interpret how to do things." Those who had not completed their doctorates seemed especially perturbed by expectations for independence. Craig stated "I feel I was just left to do my own thing." Carla became a "doctoral orphan" (Wisker \& Robinson, 2013) when a potential supervisor left the university: "I found myself with nobody to actually help me out. Just me and basically just books."

Disciplinary differences have been highlighted in studies of doctoral education (Golde, 2005). Our findings suggest that not only discipline but also other choices (program, courses, thesis topic) may serve as aspects of capital to be deployed within the labour market, whether in academe or elsewhere. For example, holding social work qualifications prior to embarking on the doctorate helped several participants secure a university teaching position in that field. Conversely, an esoteric dissertation topic made finding a match in the job market more difficult. More generally, while the equity focus of the department may have assisted some individuals to find positions in, for example, women's studies programs, its location outside of mainstream sociology may have disadvantaged others when they competed with graduates from sociology departments. Other career possibilities might also be compromised. Charlotte remarked: "I find when I say I have a doctorate, and I also say I'm doing stuff in equity, it makes me unemployable in the corporate sector." Denise reflected on the morality of offering a degree with such uncertain consequences:

Looking back now, and this is all hindsight, right, I think it was unfair to bring such a large cohort in ... you had a lot of people who were poor, seeking a dream. Like giving up everything to do their $\mathrm{PhD}$.

They wanted more honesty from the university: "You can't promise the moon if you can't deliver it" (Carla).

While the participants were quick to recite the shortcomings of their doctoral preparation and identify the inequities of the academic labour market, they also took individual responsibility for their situations. In the next section we look at the way in which they depicted their personal choices and constraints.

\section{The Habitus: Personal Responsibility and Restrictions}

Arguably, an academic habitus leads one to prize a full-time, tenured position and blame oneself for not achieving this goal. At some point in the interview, most participants showed some element of self-blame, speaking of their initial naiveté or limitations imposed by their backgrounds and family situation or their failure to do something. A poignant reflection came from Cecile: 
If there were one sense in which I was [overconfident], that was because I was always at the top of the heap. In all modesty, I mean, I had the awards, the publications, and it always felt that if anyone was going to get a job, it's going to be me because I've done everything right. Not because I was so brilliant, but because I had done everything that I had been told I needed to do in order for this to happen, and others who hadn't done it wound up getting jobs, and that was a surprise.

Put into Bourdieusian terms, Cecile believed she had acquired sufficient academic capital (awards, publications, etc.) ${ }^{4}$ and had the appropriate academic habitus to succeed in the "game" of finding a permanent academic job, only to be bewildered when it failed to happen. The only thing that Cecile thought she could have done differently would have been to move away from her family in search of wider job possibilities. Other than that, "there was not one opportunity that I passed up-conferences and papers and sitting on boards and all those things."

Not knowing initially what career outcomes to expect of a doctoral program was common: "I started doing it for the love of what I was doing, with no thought for the financial and the professional and the family consequences" (Denise). Asked if there were anything they would do differently, several participants wished they had gained teaching experience before completing their degrees. For example, Corinne said "if I look back, I would have done a sessional." Today, some commentators are emphasizing the need for graduates to display professional skills (such as teamwork or leadership) in order to access a wider variety of careers beyond academe. But few of the interviewees expressed any need for these skills although some training had been offered through the optional workshops available when they were students. Ben pointed out that, at the time, attending such a workshop was like admitting that one was not individually "meritorious enough in the PhD process" to succeed.

Both women and men believed that responsibility for others' welfare-partners, children, siblings, and parents were all mentioned-restricted their options:

Bella: The financial . . is kind of what guides my decisions. Can I support my family? Now, not only my [child] but can I help my parents who have now become more and more dependent on me?

While single parents like Bella had particular concerns, those who had a partner or wanted to start a family also saw their choices as limited by their domestic situations:

Alice: [As a student, I] did not partake in student politics or departmental committees, due to competing family responsibilities and living a distance from campus.

Denise: I was at an age where I was older and I wanted to have a child. If I had gone that route [moving for a job] I don't think I'd have [my child].

The sense of responsibility for other family members might well be part of a primary habitus shaped by a particular social or cultural background; while it has been argued that a propensity toward geographical mobility is part of the academic habitus (Bauder, 2015), acquiring an academic habitus did not, in these cases, encourage unfettered mobility.

There may be a connection with particular features of the Canadian educational landscape. Canadian universities are far less differentiated than those in the US or UK and Ca- 
nadian students tend to attend university in their home city or nearby locations (Davies \& Hammack, 2005), although students' chances of attending a distant university will be greater if they are from wealthier families (Baker, 2014; Davies, Maldonaldo, \& Zarifa, 2014). At the point of selecting a program for graduate studies, entrants may be more concerned with the availability of specialized training rather than location; yet family and finances may still limit choice. Haney's (2015) study of Canadian academics suggests that some social class disadvantages persist through graduate school and into academic employment. Moreover, by the time students have progressed to and through graduate studies, they are likely to have established relationships and families that make geographical mobility more difficult.

When the graduates in our study did go abroad, it was for a variety of reasons, including paying off student loans, being closer to relatives, collecting data, or simply because local jobs were unavailable. Interestingly, none of our mobile participants had gone to the United States for an academic position, ${ }^{5}$ a move that appears to enhance chances of being hired in a Canadian university (Gopaul \& Pifer, 2016; Groarke \& Fenske, 2009), at least in research-intensive institutions (Wilkinson, Bramadat, Dolynchuk, \& St. Aubin, 2013), but it was a choice that did not seem feasible for any of our interviewees. As Gopaul and Pifer (2016) comment, there are "strong forces of access and equity that permeate who gets to move for an academic career” (pp. 240-241).

\section{When Habitus Meets Field}

In terms of charting the impact of a primary habitus, we do not have any systematic data on our participants' social class origins or parents' education, although we know from our earlier research that many struggled financially during their graduate studies (Acker \& Haque, 2010, 2015). Our students were so diverse in terms of age, ethnicity, and time of immigration to Canada that it would have been difficult to simply give them social class labels or infer cultural capital from any simple indicator.

Nevertheless, participants' statements about their initial naiveté suggests that many came into doctoral study with a primary habitus that made that level of education, let alone the academic job market, unfamiliar. On the other hand, their experience in a graduate department will produce some version of a secondary academic habitus, and we could expect that achievements during the graduate program would give them confidence about the future. However, we saw instances such as Cecile's situation where talent and devotion to work did not seem to be rewarded with expanded job opportunities.

The clash of anticipation and reality produced a form of hysteresis for at least some of our participants. The labour market had changed (or at least differed significantly from the one they anticipated), and even those who appeared to have developed a model academic habitus and had "done everything right," like Cecile, or finished in record time, like Ben or Dinah, were no longer guaranteed smooth (or indeed, any) entry into the primary academic labour market.

Even our more successful participants (in terms of acquiring a tenure-track position, something that virtually all of our participants had expected to obtain eventually) had to reframe their ideas about academe. Both of the two participants now tenured did at least some sessional teaching before attaining the tenure track. As noted earlier, Annie held a postdoctoral appointment and taught on a temporary basis for four years before making the transition. Alice, who had secured a tenure-track job within a year of graduation, said that when offered the position, 
I called up my supervisor and said "Should I really take it?" [The supervisor] said "No, no, just take it." I don't know what I was thinking. Did I just think these jobs were like daisies that I could pick in a field? . . . As a grad student I just figured I was on this trajectory. I was going to do all these things and then at the end I would just have this job.

The three individuals not yet tenured but on the tenure track also had to learn different ways of thinking and working. Bella explained that she is now "fairly competitive" because "I came out of my PhD with 10 years of teaching experience in different settings." Bonnie described her graduate studies, personal life, and sessional teaching as "9 or 10 years of trauma," but added that "now I know how to carry myself as a real academic." For Bonnie, a "real academic" is someone who presents in a certain way and is also validated by others. She believed that the graduate school failed to convey that validation. Ben finished his doctorate quickly but then held a series of sessional teaching appointments, postdocs, and temporary contracts, both in Canada and abroad, while trying for permanent employment. Deciding that his academic identity as a particular kind of specialist was not helping him in the job market, Ben rewrote his CV and rethought his publications to make himself more competitive for mainstream positions. These examples suggest that for some job seekers in the academic field, hysteresis may be a temporary condition.

Participants in our study occupying contingent positions or working outside academe were more likely to continue in a state of hysteresis, in which their academic habitus remained at odds with the labour market. Some of our participants had to deal with repeated letdowns: "Each time I apply it's more painful, each time you get the rejection" (Charlotte); "I've applied to a few research jobs and I haven't even gotten an interview" (Dinah). Contingent faculty pointed to rewards such as enjoying teaching, working with students, and being able to remain connected to academe, but the positive portrayals were outweighed by the negative ones. While those who had not finished doctorates (two of whom still held out hope for eventual completion) might understand that their path to a tenured position was rocky, they had not expected to feel trapped in a situation where their level of privilege and support was so low.

Carla referred to "sessional hell, sessional purgatory," while Craig described "the sessional world" as "bitter, resentful, strained." Its pervasive insecurity could mean "a life of hardship and poverty" (Charlotte). Sessional work meant "teaching about everything but my area" (Candy). It meant an absence of benefits like research or conference travel support (Craig). It meant vulnerability to university cutbacks and last-minute decisions. It meant coping with full-time faculty who seemed only interested in "when can I have the photocopier" (Charlotte) and indifference to one's job security: "no one [went] to bat for me" (Cecile).

We agree with McAlpine et al. (2013) that "the personal" (or the habitus) looms large in the decision-making behaviour of doctoral graduates and has not been given enough attention. Yet former doctoral students do not simply see themselves as being subject to limitations due to their personal characteristics and the choices they have made. As earlier sections showed, they have many criticisms of the doctoral program and of the academic labour market. Sooner or later, some manage to build on the "degrees of integration" (Bourdieu, 2000, p. 161) within the academic habitus to find a resolution to the difficulty of entering the academic labour market, while others continue in a state of hysteresis. 


\section{Discussion and Conclusion}

This article has considered accounts of career experiences and encounters with the academic field of 13 former doctoral students, about a decade after an earlier study and at least that long after participants began their doctoral programs. Bourdieu's concepts of field and habitus helped us organize participants' stories around perceptions of external and internal factors that contributed to their employment outcomes.

Under current conditions of the turn towards neoliberalism in universities, the academic labour market is rapidly changing and the proportion of academic positions that offers security is declining (Acker, Haque, \& Webber, 2016; Bauder, 2015; Jones, 2013). We have described a situation where the academic habitus acquired in doctoral studies is mismatched to a labour market that offers considerably fewer slots than graduates expect and desire. There is a parallel here with Bourdieu's (1984) example of the devaluing of educational credentials dashing hopes of those who obtain them.

Our study shows that the extended period of apprenticeship necessary to have a chance to break into full-time academic employment, the sub-standard conditions of sessional work, and the hegemonic merit-based discourses that encourage self-blame were a part of the landscape in which participants functioned. People who acquired an academic habitus when they were doctoral students experienced dissonance (hysteresis) when they found themselves out of academe or unable to readily access tenure-track positions. Some found adaptations that eventually allowed them to access a full-time faculty position, while others were unable to make that leap, yet were still reluctant to let go of the dream of an academic career. Bourdieu (1988, p. 89) argues that some probability of success is required for the maintenance of an unequal academic playing field. Academics such as our participants show the disposition to play the game, and because there are some successes even after years in the contingent wilderness (e.g., Ben, Bonnie, Bella), players continue to play. After all, as Denise in our study observed, students were "giving up everything to do their PhD."

Both the graduate school and the academic labour market are part of an academic field in its wider sense, even stretching to a global market. What might be useful conceptually is a consideration of the academic field (or one within a particular nation or discipline or institution) as divided or segmented, as Bauder (2006) argues. Simplifying slightly (for example, leaving out academic-related administrative positions held by doctoral graduates), we can see either two academic fields or a sub-divided one where permanent and tenured positions and those likely to lead to permanence act as the primary labour market field and contingent ones as the secondary labour market field. Doctoral programs by definition are located in the primary market, or field, and are mostly in the more elite institutions within the field as well (Jones \& Gopaul, 2012). Students do research dissertations. Thus it is not surprising that they are oriented toward the primary market as the logical destination. In some fields, such as engineering and business, viable alternatives exist, but even then, doctoral students still frequently think in terms of the primary academic labour market (Gemme \& Gingras, 2012; Raineri, 2013). Despite talk of training students for alternative occupations and giving them greater professional development skills, no one proposes training them for a career in the secondary labour market of temporary and precarious positions. 
Our qualitative research produced hints about what choices and chances would expedite obtaining a tenure-track job: the mentoring Alice received (compare with Carla's doctoral orphan status); the persistence Ben showed through taking up multiple temporary positions, eventually changing focus to become more mainstream; helpful prior credentials such as an MSW at a time when social work university positions were easier to find; mobility to go where the jobs are; and a certain amount of university teaching experience. Conversely, long periods in stipend work, restricted mobility, esoteric thesis topics, and family commitments appear to work against one's options. Obtaining a postdoctoral appointment and completing a dissertation quickly did not appear to make a difference either way. There is no one formula; recall that Bourdieu's field is always a site of struggle.

Future quantitative research might include varied subject fields and larger numbers and could analyze in a systematic way the impact of characteristics similar to those listed above. We think that studies that consider whether doctoral graduates are employed directly after or within a few years of graduation may miss the extent to which individuals move in and out of contingent work (before and after completing the doctorate) and the number of years it may take to find a tenure-track job. A longitudinal study might better take into account labour market fluctuations. When the labour market is tight, factors that may in better times be irrelevant (e.g., esoteric thesis topics) begin to make a difference to employment opportunities. Similarly, we argue that while most of the popular discussion has focused on the preparation and outlook of individual job-seekers, equal attention should be paid to the field: how is it that institutions can continue to operate such an inegalitarian, divided system in which tenured academics are for the most part complicit?

It is well to remember that not all explanations lie within the individual's volition or the academic field. Universities respond to restricted funding and external pressures to operate like corporations (Bauder, 2006; Newson, 2012). The academic field is not the only site of struggle; rather, the "field is a critical mediation between the practices of those who partake of it and the surrounding social and economic conditions" (Bourdieu \& Wacquant, 1992, p. 105).

\section{References}

Acker, S. (2001). The hidden curriculum of dissertation advising. In E. Margolis (Ed.), The hidden curriculum in higher education (pp. 61-77). New York, NY: Routledge.

Acker, S., \& Haque, E. (2010). Doctoral students and a future in academe? In L. McAlpine \& G. Åkerlind (Eds.), Becoming an academic: International perspectives (pp. 96-124). Basingstoke, UK: Palgrave Macmillan.

Acker, S., \& Haque, E. (2015). The struggle to make sense of doctoral study. Higher Education Research and Development, 34(2), 229-241.

Acker, S., Haque, E., \& Webber, M. (2016). The two faces of flexibility: Careers and jobs in contemporary academe. In G. Wisker, L. Marshall, S. Greener, \& J. Canning (Eds.), Flexible futures (pp. 51-60). Falmer, UK: University of Brighton.

Albert, M., \& Kleinman, D. K. (2011). Bringing Pierre Bourdieu to science and technology studies. Minerva, 49, 263-273. 
Andres, L., \& Adamuti-Trache, M. (2008). Life-course transitions, social class, and gender: A 15-year perspective of the lived lives of Canadian young adults. Journal of Youth Studies, 11(2), 115-145.

Baker, J. (2014). No Ivies, Oxbridge, or grandes écoles: Constructing distinctions in university choice. British Journal of Sociology of Education, 35(6), 914-932.

Bathmaker, A.-M., Ingram, N., \& Waller, R. (2013). Higher education, social class and the mobilisation of capitals: Recognising and playing the game. British Journal of Sociology of Education, 34(5-6), 723-743.

Bauder, H. (2006). The segmentation of academic labour: A Canadian example. ACME: An International Journal for Critical Geographies, 4(2), 228-239.

Bauder, H. (2015). The international mobility of academics: A labour market perspective. International Migration, 53(1), 83-96.

Bourdieu, P. (1975). The specificity of the scientific field and the social conditions of the progress of reason. Social Science Information, 14(6), 19-47

Bourdieu, P. (1984). Distinction. London: Routledge.

Bourdieu, P. (1986). The forms of capital. In J. G. Richardson (Ed.), Handbook of theory and research for the sociology of education (pp. 241-258). New York, NY: Greenwood Press.

Bourdieu, P. (1988). Homo academicus. Palo Alto, CA: Stanford University Press.

Bourdieu, P. (1998). Practical reason on the theory of action. Cambridge, UK: Polity Press.

Bourdieu, P. (2000). Pascalian meditations. Cambridge, UK: Polity Press.

Bourdieu, P. (2004). Science of science and reflexivity. Chicago: University of Chicago Press.

Bourdieu, P., \& Wacquant, L. (1992). An invitation to reflexive sociology. Chicago, IL: University of Chicago Press.

Brownlee, J. (2015). Contract faculty in Canada: Using access to information requests to uncover hidden academics in Canadian universities. Higher Education, 70, 787-805.

Chiose, S. (2015, March 6). For 10,000 of Canada's young academics on the picket lines, there's a lot more at stake than $\$ 42$ an hour. The Globe and Mail. Retrieved from http:// www.theglobeandmail.com/news/toronto/for-1000o-of-canadas-young-academics-onthe-picket-lines-theres-a-lot-more-at-stake-than-42-an-hour/article23346532/

Davies, S., \& Hammack, F. (2005). The channeling of student competition in higher education: Comparing Canada and the U.S. Journal of Higher Education, 76(1), 89-106.

Davies, S., Maldonado, V., \& Zarifa, D. (2014). Effectively maintaining inequality in Toronto: Predicting student destinations in Ontario universities. Canadian Review of Sociology, 51(1), 22-53.

Deem, R., \& Lucas, L. (2007). Research and teaching cultures in two contrasting UK policy contexts: Academic life in education departments in five English and Scottish universities. Higher Education, 54, 115-133. 
Edge, J., \& Munro, D. (2015). Inside and outside the academy: Valuing and preparing PhDs for careers. Ottawa, ON: The Conference Board of Canada. Retrieved from http:// www.conferenceboard.ca/e-library/abstract.aspx?did $=7564$

Ferguson, S.J., \& Wang, S. (2014). Graduating in Canada: Profile, labour market outcomes and student debt of the class of 2009-2010 Revised. Ottawa, ON: Statistics Canada. Retrieved from http://www.statcan.gc.ca/pub/81-595-m/81-595-m2014101eng.pdf

Field, C., \& Jones, G.A. (2016). A survey of sessional faculty in Ontario publiclyfunded universities (Research Report 2016.04). Retrieved from OISE-University of Toronto website http://www.oise.utoronto.ca/hec/UserFiles/File/Sessional_Faculty_-_ OHCRIF_Final_Report_-_July_2016.pdf

Fullick, M. (2013, April 12). Who will hire all the PhDs? Not Canada's universities. The Globe and Mail. Retrieved from http://www.theglobeandmail.com/news/national/ education/who-will-hire-all-the-phds-not-canadas-universities/article10976412/

Gardner, S., \& Holley, K. (2011). “Those invisible barriers are real”: The progression of first-generation students through doctoral education. Equity and Excellence in Education, 44(1), 77-92.

Gemme, B., \& Gingras, Y. (2012). Academic careers for graduate students: A strong attractor in a changed environment. Higher Education, 63(6), 667-683.

Gillis, C. (2013, June 3). Are Ph.D.s an academic dead zone? Maclean's Magazine. Retrieved from http://www.macleans.ca/society/life/an-academic-dead-zone/

Golde, C. M. (2005). The role of the department and discipline in doctoral student attrition: Lessons from four departments. Journal of Higher Education, 76(6), 669-700.

Golovushkina, E., \& Milligan, C. (2012). Developing early stage researchers: Employability perceptions of social science doctoral candidates. International Journal for Researcher Development, 3(1), 64-78.

Gopaul, B. (2011). Distinction in doctoral education: Using Bourdieu's tools to assess the socialization of doctoral students. Equity and Excellence in Education, 44(1), 10-21.

Gopaul, B. (2015). Inequality and doctoral education: Exploring the "rules" of doctoral study through Bourdieu's notion of field. Higher Education, 70, 73-88.

Gopaul, B., \& Pifer, M. (2016). The conditions of movement: A discussion of academic mobility between two early career scholars. Higher Education Quarterly, 7O(3), 225-245.

Groarke, L., \& Fenske, W. (2009). PhD: To what end? University Affairs, November 9.

Haney, T. J. (2015). Socioeconomic difference and the educational experiences of university professors. Canadian Review of Sociology, 52(2), 160-186.

Jones, G. A. (2013). The horizontal and vertical fragmentation of academic work and the challenge for academic governance and leadership. Asia Pacific Education Review, $14,75-83$. 
Jones, G. A., \& Gopaul, B. (2012). Doctoral education and the global university: Student mobility, hierarchy and Canadian federal policy. In A. Newson \& I. Wei (Eds.), The global university: Past, present and future perspectives (pp. 189-209). London, UK: Palgrave Macmillan.

Jonker, L. (2016). Ontario's PhD graduates from 2009: Where are they now? Toronto, ON: Higher Education Quality Council of Ontario.

Kehm, B. (2009). Doctoral education: Pressures for change and modernisation. In J. Enders \& E. de Weert (Eds.), The changing face of academic life (pp. 155-170). Basingstoke, UK: Palgrave Macmillan.

Lee, E. M., \& Kramer, R. (2013). Out with the old, in with the new? Habitus and social mobility at selective colleges. Sociology of Education, 86(1), 18-35.

Lehmann, W. (2013). In a class of their own: How working-class students experience university. In R. Brooks, M. McCormack, \& K. Bhopal (Eds.), Contemporary debates in the sociology of education (pp. 93-111). Basingstoke, UK: Palgrave Macmillan.

Lucas, L. (2006). The research game in academic life. Maidenhead, UK: Open University Press.

Maldonado, V., Wiggers, R., \& Arnold, C. (2013). So you want to earn a PhD? Toronto, ON: Higher Education Quality Council of Ontario.

Manathunga, C., Pitt, R., \& Critchley, C. (2009). Graduate attribute development and employment outcomes: Tracking PhD graduates. Assessment \& Evaluation in Higher Education, 34(1), 91-103.

Manderson, D., \& Turner, S. (2006). Coffee house: Habitus and performance among law students. Law and Social Inquiry, 31(3), 649-676.

McAlpine, L. (2012). Academic work and careers: Relocation, relocation, relocation. Higher Education Quarterly, 66(2), 174-188.

McAlpine, L., Amundsen, C., \& Turner, G. (2013). Constructing post-PhD careers: Negotiating opportunities and personal goals. International Journal for Researcher Development, 4(1), 39-54.

Mellors-Bourne, R., Metcalfe, J., \& Pollard, P. (2013). What do researchers do? Early career progression of doctoral graduates. Retrieved from https://www.sheffield.ac.uk/ polopoly_fs/1.379269!/file/what-do-researchers-do-early-career-progression-2013.pdf

Mendoza, P., Kuntz, A., \& Berger, J. (2012). Bourdieu and academic capitalism: Faculty "habitus" in materials science and engineering. Journal of Higher Education, 83(4), 558-581.

Modern Language Association of America. (2014). Report of the MLA task force on doctoral study in modern language and literature. Retrieved from https://apps.mla. org/pdf/taskforcedocstudy2014.pdf

Morrison, E., Rudd, E., \& Nerad, M. (2011). Early careers of recent U.S. social science PhDs. Learning and Teaching, 4(2), 6-29.

Mullen, A. (2010). Degrees of inequality. Baltimore, MD: Johns Hopkins University Press. 
Mullen, A., Goyette, K., \& Soares, J. (2003). Who goes to graduate school? Social and academic correlates of educational continuation after college. Sociology of Education, $76(2), 143-169$.

Naidoo, R. (2004). Fields and institutional strategy: Bourdieu on the relationship between higher education, inequality and society. British Journal of Sociology of Education, 25(4), 457-471.

Neumann, R., \& Tan, K. (2011). From PhD to initial employment: The doctorate in a knowledge economy. Studies in Higher Education, 36(5), 601-614.

Newson, J. (2012). The university-on-the-ground: Reflections on the Canadian experience. In M. Luxton \& M. J. Mossman (Eds.), Reconsidering knowledge: Feminism and the academy (pp. 96-127). Halifax, NS: Fernwood.

OCUFA [Ontario Confederation of University Faculty Associations]. (2014, April 30). Data check: Teaching by precarious faculty in Ontario jumps. Retrieved from http:// ocufa.on.ca/blog-posts/data-check-teaching-by-precarious-faculty-in-ontario-jumps.

OECD [Organisation for Economic Cooperation and Development]. (2012). Transferable skills training for researchers: Supporting career development and research. Retrieved from https://www.abc.org.br/IMG/pdf/doc-4500.pdf

Platow, M.J. (2012). PhD experience and subsequent outcomes: A look at selfperceptions of acquired graduate attributes and supervisor support. Studies in Higher Education, 37(1), 103-118.

Raineri, N. (2013). The PhD program: Between conformity and reflexivity. Journal of Organizational Ethnography, 2(1), 37-56.

Reay, D., David, M. E., \& Ball, S. (2010). Degrees of choice. Stoke on Trent, UK: Trentham.

Sekular, A., Crow, B., \& Annan, R. (2013). Beyond labs and libraries: Career pathways for doctoral students. Toronto, ON: Higher Education Quality Council of Ontario.

Statistics Canada (2012). Number of full-time teaching staff at Canadian universities, by rank and sex, Canada and provinces. Table 477-0017. Retrieved from http://www. statcan.gc.ca/tables-tableaux/sum-som/lo1/csto1/educ68a-eng.htm.

Tamburri, R. (February 6, 2013). The PhD is in need of revision. University Affairs.

Tesch, R. (1990). Qualitative research: Analysis types and software tools. New York, NY: Falmer.

White paper on the future of the PhD in the humanities (2013). Montreal, QC: Institute for the Public Life of Arts and Ideas, McGill University.

Wilkinson, L., Bramadat, J., Dolynchuk, R., \& St. Aubin, Z. T. (2013). Are Canadiantrained PhDs disadvantaged in the academic labour market? Canadian Review of Sociology, 5o(3), 357-370.

Wisker, G., \& Robinson, G. (2013). Doctoral 'orphans': Nurturing and supporting the success of postgraduates who have lost their supervisors. Higher Education Research \& Development, 32(2), 300-313. 
Wood, L. M., \& Townsend, R. B. (2013). The many careers of history PhDs: A study of job outcomes, Spring 2013. A report to the American Historical Association. Retrieved from https://www.historians.org/Documents/Many_Careers_of_History_PhDs_Final.pdf

Zipin, L., \& Brennan, M. (2003). The suppression of ethical dispositions through managerial governmentality: A habitus crisis in Australian higher education. International Journal of Leadership in Education, 6(4), 351-370.

\section{Notes}

$1 \quad$ For example, 25 of the original group of 31 (81\%) had graduated, compared with 10 of the 13 (77\%) re-interviewed. In both cases, elapsed time between original doctoral registration (beginning after a master's degree) and degree completion ranged from 4 to 15 years.

2 We classified our 31 original participants into 10 tenured faculty; three on the tenure track; 11 in contingent academic work; five in stable non-university careers; and two in other/unknown.

3 While we were writing this article, Denise began teaching sessional university evening classes in addition to her full-time day job.

4 In Cecile's case, we are aware that she held Tri-Council doctoral and postdoctoral scholarships and had published a book. However, it is important to note that we are reporting perceptions; as noted in the text, we did not examine CVs or collect any data on publications.

5 In our tracking of the 31 original participants, we found no evidence that anyone had moved to the United States for an academic position.

\section{Contact Information}

Sandra Acker

Department of Social Justice Education

Ontario Institute for Studies in Education

University of Toronto

sandra.acker@utoronto.ca

Sandra Acker is a Professor Emerita in the Department of Social Justice Education, University of Toronto. She has worked in the United States, United Kingdom, and Canada. Her research has focused on changes in academic work, university tenure practices, women academics in leadership positions, doctoral student and graduate experiences, and research project leadership. She is the author of Gendered Education (1994) and The Realities of Teachers' Work (1999) and co-editor of Whose University Is It, Anyway? Power and Privilege on Gendered Terrain (2008), as well as numerous chapters and journal articles.

Eve Haque is an Associate Professor in the Department of Languages, Literatures and Linguistics at York University. Her research and teaching interests include multiculturalism, white settler nationalism, and language policy, with a focus on the regulation and representation of racialized im/migrants in white settler societies. She has also investigated the experiences of doctoral students and doctoral graduates. She has published in 
the journals Social Identities, Higher Education Research and Development, and Pedagogy, Culture and Society, among others. She is the author of Multiculturalism within a Bilingual Framework: Language, Race and Belonging in Canada (University of Toronto Press, 2012). 